\title{
PENGARUH BAURAN PEMASARAN JASA TERHADAP KEPUTUSAN MEMILIH PADA MAHASISWA SEKOLAH TINGGI ILMU MANAJEMEN INDONESIA (STIMI) - MEULABOH
}

\author{
Chairiyaton $^{1}$, Nani Verawati ${ }^{2}$ \\ ${ }^{1}$ Universitas Teuku Umar \\ ${ }^{2}$ Universitas Teuku Umar
}

\begin{abstract}
Abstratc: The objective of this research was to analyze the influence of marketing mix strategy consisted of product, price, location, people, process, and tangibles on decision to choose at STIMI, Meulaboh.The research used descriptive statistical method with descriptive explanatory approach. The data were gathered by conducting interviews, questionnaires, and documentary study. The population was all students of STIMI, Meulaboh, in the academic year of 2013, and 106 of them were used as the samples. Measuring scale used interval scale and analyzed by using multiple linear regresstion. The result of equation showed that, simultaneously, the variables of product, price, location, people, process, and tangibles could influence decision to choose STIMI, Meulaboh. Partially, product had positive and direct influence on decision to choose at STIMI, Meulaboh. price had positive and direct influence on decision to choose, location had positive and direct influence on decision to choose, people had positive and direct influence on decision to choose, process had positive and direct influence on decision to choose, and tangibles had positive and direct influence on decision to choose at STIMI, Meulaboh.
\end{abstract}

Abstrak: Tujuan dari penelitian ini adalah untuk menganalisis pengaruh bauran pemasaran yang terdiri dari produk, harga, lokasi, orang, proses, dan bukti fisik terhadap keputusan memilih di STIMI Meulaboh. Penelitian ini menggunakan metode statistik deskriptif dengan pendekatan deskriptif eksplanatori. Data dikumpulkan dengan melakukan wawancara, kuesioner, dan studi dokumentasi. Populasi adalah semua mahasiswa STIMI, Meulaboh, pada tahun akademik 2013, dan 106 di antaranya digunakan sebagai sampel. Skala pengukuran menggunakan skala interval dan dianalisis dengan menggunakan analisis regresi linier berganda. Hasil persamaan menunjukkan bahwa, secara bersamaan, variabel produk, harga, lokasi, orang, proses, dan bukti fisik dapat mempengaruhi keputusan untuk memilih STIMI, Meulaboh. Secara parsial, produk memiliki pengaruh positif dan langsung pada keputusan untuk memilih siswa di STIMI, Meulaboh. harga berpengaruh positif dan langsung pada keputusan untuk memilih, lokasi memiliki pengaruh positif dan langsung pada keputusan untuk memilih, orang memiliki pengaruh positif dan langsung pada keputusan untuk memilih siswa, proses memiliki positif dan langsung pengaruh terhadap keputusan untuk memilih, dan bukti fisik memiliki pengaruh positif dan langsung pada keputusan untuk memilih di STIMI, Meulaboh.

Keywords: Marketing Mix, Decision to Choose 


\section{Jurnal Bisnis dan Kajian Strategi Manajemen}

Volume 3 Nomor 1, 2019

ISSN : 2614-2147

\section{PENDAHULUAN}

Mendapatkan Pendidikan formal merupakan jalan alternatif yang dapat dipilih setiap individu untuk mengoptimalkan kemampuan diri dengan harapan akan mendapatkan kehidupan yang lebih baik ditengah semakin besarnya tingkat persaingan dalam mendapatkanberbagai peluang yang ada.Kondisi yang seperti ini merupakan salah satu faktor yang mendorong meningkatnya kesadaran para orang tua akan pentingnya memberikan pendidikan bagi anak-anak mereka hingga jenjang perguruan tinggi.

Perguruan tinggi perlu mengetahui pelayanan yang telah diberikan kepada mahasiswanya, sehingga mahasiswa merasa puas. Dalam hal ini bisa berupa manajemen yang rapi, kualitas proses pembelajaran, fasilitas yang diberikan, dan layanan adminstrasi. Perguruan tinggi harus memiliki strategi untuk dapat mempertahankan keberadaannya, supaya dapat bersaing dengan perguruan tinggi yang lain. Hal ini dapat dicapai dengan mengembangkan dan menyajikan bauran pemasaran yang diarahkan pada pasar sasaran yang dipilih. Bauran pemasaran yang terkait dengan jasa, meliputi produk, harga, promosi, lokasi, proses, orang, serta pelayanan (Kotler, 2012).

Kondisi persaingan yang tinggi ini juga terjadi pada perguruan tinggi - perguruan tinggi swasta di Kabupaten Aceh Barat di tambah lagi dengan kehadiran tiga PTN baru pada tahun 2014 yang lalu sehingga PTS-PTS di kabupaten ini harus semakin jeli dalam memamfaatkan peluang-peluang yang ada, untuk itu PTS-PTS ini harus terus berbenah dan berusaha mencari apa yang sebenarnya di inginkan oleh calon mahasiswa sebagai konsumen sehingga dengan demikian pihak PTS akan lebih mampu Menciptakan Kepuasan bagi mahasiswa sebagai konsumennya. Kemampuan memberikan kepuasan yang di anggap paling mampu memberikan jawaban sebagai solusi atas kebutuhan konsumen adalah indikator yang juga menjadi pertimbagan yang mampu mempengaruhi keputusan mereka untuk memilih PTS tersebut sehingga keberlangsungan hidup PTS akan tetap berlanjut. 


\section{Jurnal Bisnis dan Kajian Strategi Manajemen}

Volume 3 Nomor 1, 2019

ISSN : 2614-2147

\section{KAJIAN KEPUSTAKAAN}

\section{Produk (product)}

Kotler (2008) mendefiniskan produk adalah segala sesuatu yang dapat ditawarkan kepada pasar untuk memuaskan suatu kebutuhan atau keinginan, termasuk barang fisik, jasa, pengalaman, acara, orang, tempat, properti, organisasi, informasi dan ide. Persaingan di pasar memaksa perusahaan untuk mengupayakan adaptasi produk yang tinggi guna meraih keunggulan yang kompetitif atas pesaing, karena adaptasi produk dapat memperluas basis pasar lokal dan ditingkatkan untuk preferensi lokal tertentu

\section{Harga (price)}

Tjiptono (2014) menyatakan bahwa “ Dalam konteks pemasaran jasa,secara sederhana istilah harga dapat diartikan sebagai jumlah uang (satuan moneter) dan atau aspek lain (non-moneter) yang mengandung utilitas/kegunaan tertentu yang diperlukan untuk mendapatkan suatu jasa. Utilitas merupakan atribut atau faktor yang berpotensi memuaskan kebutuhan dan keinginan tertentu.

\section{Lokasi (place)}

Adam (2015) menyatakan bahwa lokasi berhubungan dengan keputusa yang dibuat oleh perusahaan mengenai dimana operasi dan stafnya akan di tempatkan. Menurut Payne (2001) Tempat yang digunakan untuk memasok jasa kepada pelanggan sasaran merupakan dua budang keputusan kunci”. Keputusankeputusan tempat (lokasi dan saluran) meliputi perkembangan mengenai cara menyampaikan jasa kepada pelanggan dan di mana jasa harus ditempatkan.

\section{Proses (process)}

Lupiyoadi (2006) menyatakan "Proses merupakan gabungan semua aktivitas, umumnya terdiri dari prosedur, jadwal pekerjaan, aktivitas dan hal-hal rutin, dimana suatu jasa dihasilkan dan disampaikan kepada konsumen. Shostack dalam Yazid (2008) menyarankan proses jasa dapat didefenisikan dalam terminologi-terminologi: variabel kompleksitas (convergence) dan variabel fleksibelitas (divergence). Kompleksitas mencerminkan sejumlah langkah yang terlibat dalam penyampaian jasa fleksibilitas mencerminkan rentang (naik turunya level) eksekusi atau variabelitas langkah-kangkah tersebut. 


\section{Jurnal Bisnis dan Kajian Strategi Manajemen}

Volume 3 Nomor 1, 2019

ISSN : 2614-2147

\section{Orang (people)}

Menurut Lupiyoadi (2006) Dalam hubungannya dengan pemasaran jasa, maka people berfungsi sebagai service Provider sangat mempengaruhi kualitas jasa yang diberikan. Keputusan dalam hal ini beraati berhubungan dengan seleksi,pelatihan dan motivasi serta manajemen sumber daya manusia. Yazid (2008) menyatakan Orang (people) adalah semua pelaku yang memainkan sebagian penyajian jasa dan karenanya mempengaruhi persepsi pembeli. Yang termasuk dalam elemen ini adalah personel perusahaan, konsumen, dan konsumen lain dalam lingkungan jasa.

\section{Bukti Fisik (Physical Evidence)}

Zeithaml and Bitner dalam Ratih Hurriyati (2005) menyatakan bahwa: Physical evidence (sarana fisik) ini merupakan suatu hal yang secara turut mempengaruhi keputusan konsumen untuk membeli dan menggunakan produk jasa yang di tawarkan. Menurut Yazid (2008) bahwa Lingkungan fisik merupakan elemen substansif dalam suatu konsep jasa. Oleh karena itu para pemasar jasa semestinya terlibat dalam suatu proses desain, perencanaan, dan pengawasan bukti fisik.

\section{Keputusan Pembelian (Buying Decision)}

Proses Keputusan Pembelian Konsumen merupakan urutan-urutan kejadian yang dimulai dari pengenalan akan kebutuhan kemudian pencarian imformasi atas kebutuhan tersebut setelah itu melakukan evaluasi alternatif dan akhirnya melakukan keputusan pembelian serta diakhiri dengan perilaku setelah pembelian. Jadi jelas sekali proses pembelian dimulai jauh sekali sebelum pembelian aktual dilakukan dan mempunyai konsekuensi yang lama setelah pembelian terjadi. Menurut Sangadji dan Sopiah (2013) Pengambilan keputusan konsumen adalah proses pemecahan masalah yang diarahkan pada sasaran.

\section{METODE PENELITIAN}

\section{Jenis dan Sifat Penelitian}

Jenis penelitian ini adalah deskriptif kuantitatif yaitu untuk mengetahui pengaruh variabel bauran produk, harga, proses terhadap kepuasan mahasiswa. Adapun sifat penelitian ini adalah explanatory research. 


\section{Jurnal Bisnis dan Kajian Strategi Manajemen}

Volume 3 Nomor 1, 2019

ISSN : 2614-2147

\section{Tempat dan Waktu Penelitian}

Penelitian ini dilakukan pada STIMI Meulaboh yang berlokasi di Jln.Meulaboh-Tapaktuan Kecamatan Meureubo Kabupaten Aceh Barat dan dilaksanakan dari bulan April 2016 hingga bulan Juni 2016.

\section{Populasi dan Sampel}

Populasi dalam penelitian ini adalah seluruh mahasiswa STIMI Meulaboh Kabupaten Aceh Barat mahasiswa angkatan tahun 2014 yang terbagi dalam dua program studi dengan pertimbangan mahasiswa angkatan tersebut pada saat penelitian sudah berada di semester tengah artinya telah relatif lama berinteraksi dengan lembaga perguruan tinggi.

Berdasarkan pendapat Arikunto (2006) yang menyatakan apabila subjek kurang dari 100, maka sampel lebih baik diambil semua. Selanjutnya jika lebih besar dari 100, maka sampel dapat diambil antara 10\%-15\%,atau 20\%-25\% atau lebih maka penentuan jumlah sampel dalam penelitian ini adalah $40 \%$ dari jumlah populasi 264 orang sehingga diperoleh sampel sebesar: $n=264 \times 40 \%=106$ orang.

\section{Teknik Pengumpulan Data}

Teknik pengumpulan data dilakukan dalam penelitian ini adalah sebagai berikut:

1. Daftar Pertanyaan (questionare) diberikan langsung kepada mahasiswa yang menjadi responden dalam penelitian ini.

2. Studi dokumentasi dengan mengumpul-kan dan menganalisi data atau dokumen yang mendukung penelitian ini yaitu jumlah mahasiswa STIMI Meulaboh Kabupaten Aceh Barat mulai Tahun 2011 sampai dengan 2015 serta data-data lainnya.

\section{Jenis dan Sumber Data}

Jenis data yang akan dikumpulkan dalam penelitian ini adalah bersumber dari:

1. Data Primer merupakan data yang diperoleh dari jawaban daftar pertanyaan yang diberikan kepada mahasiswa sebagai responden pada STIMI Meulaboh. 


\section{Jurnal Bisnis dan Kajian Strategi Manajemen}

Volume 3 Nomor 1, 2019

ISSN : 2614-2147

2. Data sekunder yaitu data yang diperoleh dari studi dokumentasi seperti: Jurnal peraturan-peraturan dan dokumen-dokumen lain yang berhubungan dengan penelitian ini.

\section{Teknik Analisis Data}

Teknik analisis data pada pengujian hipotesis menggunakan analisis regresi linier berganda yang merupakan teknik statistik yang digunakan untuk menguji pengaruh antara dua atau lebih variabel dan untuk melihat pengaruh secara parsial dan simultan. Persamaan model empiris yang digunakan untuk meneliti pengaruh variabel independen terhadap variabel dependen yaitu:

$$
\mathrm{Y}=\mathrm{b}_{1} \mathrm{X}_{1}+\mathrm{b}_{2} \mathrm{X}_{2}+\mathrm{b}_{3} \mathrm{X}_{3}+\mathrm{b}_{4} \mathrm{X}_{4}+\mathrm{b}_{5} \mathrm{X}_{5}+\mathrm{b}_{6} \mathrm{X}_{6}+\mathrm{b} 7 \mathrm{Z}+\mathrm{e}
$$

Dimana:

$$
\begin{array}{ll}
\mathrm{Y} & =\text { Keputusan Memilih } \\
\left(\mathrm{X}_{1}\right) & =\text { Produk } \\
\left(\mathrm{X}_{2}\right) & =\text { Harga } \\
\left(\mathrm{X}_{3}\right) & =\text { Lokasi } \\
\left(\mathrm{X}_{4}\right) & =\text { Orang } \\
\left(\mathrm{X}_{5}\right) & =\text { Proses } \\
\left(\mathrm{X}_{6}\right) & =\text { Bukti Fisik } \\
\mathrm{e} & =\text { error terms }
\end{array}
$$

\section{HASIL DAN PEMBAHASAN}

\section{Hasil Uji Determinasi $\left(\mathbf{R}^{\mathbf{2}}\right)$ Model Persamaan Regresi}

Hasil uji determinasi untuk model persamaan regresi berganda dapat dilihat pada Tabel 1 berikut ini: 


\section{Jurnal Bisnis dan Kajian Strategi Manajemen}

Volume 3 Nomor 1, 2019

\section{Tabel 1}

Hasil Analisis Jalur R-Square Regresi

Model Summary ${ }^{\mathrm{b}}$

\begin{tabular}{|l|c|c|c|c|c|}
\hline Mod & $\mathrm{R}$ & $\mathrm{R}$ & Adjuste & Std. & Durbi \\
el & & $\begin{array}{c}\text { Squar } \\
\mathrm{d} \mathrm{R}\end{array}$ & $\begin{array}{c}\text { Error } \\
\mathrm{n}-\end{array}$ \\
& & $\begin{array}{c}\text { Square } \\
\text { of the } \\
\text { Estimat } \\
\mathrm{e}\end{array}$ & $\begin{array}{c}\text { Wats } \\
\text { on }\end{array}$ \\
\hline 1 & $.977^{\mathrm{a}}$ & .954 & .951 & .1939 & 1.709 \\
\hline
\end{tabular}

a. Predictors: (Constant), X7, X3, X1, X6,

$\mathrm{X} 4, \mathrm{X} 2, \mathrm{X} 5$

b. Dependent Variable: Y

Sumber: Output SPSS, datadiolah peneliti,

2016

Berdasarkan Tabel 2, nilai koefisien determinasi $R^{2}$ terletak pada kolom $R$-Square adalah sebesar $R^{2}=0,954$. Namun karena jumlah indikator penelitian yang tidak sama, nilai yang digunakan adalah nilai Adjusted $\mathrm{R}^{2}=95,1 \%$. Hal ini mengindikasikan bahwa model persamaan mampu menjelaskan 95,1\% variansi yang terjadi pada variabel $\mathrm{Y}$ atau variabel keputusan memilih. Bauran pemasaran yang terdiri dari 7P untuk pemasaran jasa mempengaruhi 95,1\% keputusan memilih mahasiswa. Sisanya, 4,9\% dari keputusan memilih dari mahasiswa dipengaruhi oleh faktor lain di luar bauran pemasaran, misalnya ajakan dari rekan atau orang tua

\section{Pengujian Secara Serempak (Uji F)}

Pengujian hubungan secara simultan, yaitu bauran pemasaran jasa yang terdiri dari variabel produk, harga, promosi, lokasi, orang, proses, dan bukti fisikterhadap variabel Keputusan memilih menggunakan ANOVA atau uji-F seperti yang ditunjukkan pada Tabel 3. Berdasarkan Tabel 3 diperoleh nilai $F_{\text {hitung }}$ sebesar 290.433> $\mathrm{F}_{\text {tabel }}$ sebesar 2.035dan sig $=0,000<0,05$. Oleh karena itu $\mathrm{H}_{0}$ ditolak dan $\mathrm{H}_{1}$ diterima yang berarti bahwa variabel independen (yaitu produk, 


\section{Jurnal Bisnis dan Kajian Strategi Manajemen}

Volume 3 Nomor 1, 2019

ISSN : 2614-2147

harga, lokasi, orang, proses, dan bukti fisik) secara simultan berpengaruh signifikan terhadap keputusan memilih.

Hasil pengujian dapat dilihat dari angka-angka perhitungan pada Tabel 2 berikut ini:

Tabel 2

Hasil Uji Simultan (Uji F) Model Regresi

ANOVA $^{\mathrm{a}}$

\begin{tabular}{|c|c|c|c|c|c|c|}
\hline \multicolumn{2}{|c|}{ Model } & $\begin{array}{l}\text { Sum of } \\
\text { Squares }\end{array}$ & Df & $\begin{array}{l}\text { Mean } \\
\text { Square }\end{array}$ & $\mathrm{F}$ & Sig. \\
\hline \multirow{3}{*}{1} & Regression & 76.456 & 7 & 10.922 & 290.433 & $.000^{\mathrm{b}}$ \\
\hline & Residual & 3.685 & 98 & .038 & & \\
\hline & Total & 80.142 & 105 & & & \\
\hline
\end{tabular}

a. Dependent Variable: $\mathrm{Y}$

b. Predictors: (Constant), X6, X1, X5, X4, X2, X4

Sumber: Output SPSS, data diolah peneliti, 2016

\section{Pengujian Secara Parsial (Uji-t)}

Hasil pengujian secara parsial (Uji t) persamaan struktural 1 dapat dilihat pada Tabel 3 berikut:

Tabel 3

Hasil Uji Parsial (Uji t) Model Regresi

\begin{tabular}{|c|c|c|c|c|c|}
\hline \multirow[t]{2}{*}{$\longdiv { \text { Model } }$} & \multicolumn{2}{|c|}{$\begin{array}{l}\text { Unstandardized } \\
\text { Coefficients }\end{array}$} & \multirow{2}{*}{$\begin{array}{c}\begin{array}{c}\text { Standardized } \\
\text { Coefficients }\end{array} \\
\text { Beta }\end{array}$} & \multirow[t]{2}{*}{$\mathrm{t}$} & \multirow[t]{2}{*}{ Sig. } \\
\hline & B & Std. Error & & & \\
\hline (Constant) & -1.238 & .265 & & -4.666 & .000 \\
\hline $\mathrm{X} 1$ & 127 & .045 & 106 & 2.835 & .006 \\
\hline $1 \quad \mathrm{X} 2$ & 157 & .053 & .137 & 2.950 & .004 \\
\hline X3 & .234 & .049 & .214 & 4.828 & .000 \\
\hline $\mathrm{X} 4$ & .541 & .052 & .515 & 10.425 & .000 \\
\hline
\end{tabular}




\section{Jurnal Bisnis dan Kajian Strategi Manajemen}

Volume 3 Nomor 1, 2019

ISSN : 2614-2147

\begin{tabular}{|l|l|l|l|l|l|}
$\mathrm{X} 5$ & .138 & .050 & .093 & 2.731 & .007 \\
$\mathrm{X} 6$ & .125 & .051 & .111 & 2.475 & .015 \\
& & & & & \\
\hline
\end{tabular}

a. Dependent Variable: Y

\section{Produk}

Berdasarkan Tabel 4 dapat diketahui bahwa t hitung $=2.835>\mathrm{t}$ tabel $=$ 1.985, dan signifikansi $=0.006<0.05$ maka $\mathrm{H}_{0}$ ditolak artinya produk berpengaruh positif dan signifikan terhadap keputusan mahasiswa memilih STIMI Meulaboh. Besarnya pengaruh produk terhadap keputusan memilih dilihat pada standardized coefficient (beta) sebesar 0.106 artinya jika terjadi peningkatan 1 persepsi atas produk semakin meningkat maka akan meningkatkan keputusan memilih STIMI Meulaboh.

\section{Harga}

Berdasarkan Tabel 4 dapat diketahui bahwa $\mathrm{t}$ hitung $=2.950>\mathrm{t}$ tabel $=$ 1.985, dan signifikansi $=0.004<0.05$ maka H0 ditolak artinya harga berpengaruh positif dan signifikan terhadap keputusan mahasiswa memilih STIMI Meulaboh. besarnya pengaruh harga terhadap keputusan memilih dilihat pada standardized coefficient (beta) sebesar 0.137 artinya jika persepsi atas harga semakin membaik, maka keputusan memilih mahasiswa di STIMI Meulaboh semakin membaik pula. Perbakan persepsi sebesar 1 atas harga akan meningkatkan keputusan sebesar 0.137 .

\section{Lokasi}

Berdasarkan Tabel 4 dapat diketahui bahwa t hitung $=4.828>\mathrm{t}$ tabel $=$ 1.985, dan signifikansi $=0.000<0.05$ maka $\mathrm{H}_{0}$ ditolak artinya lokasi berpengaruh positif dan signifikan terhadap keputusan mahasiswa memilih STIMI Meulaboh. Besarnya pengaruh lokasi terhadap keputusan memilih dilihat pada standardized coefficient (beta) sebesar 0.214 atau $21.4 \%$ artinya jika persepsi atas lokasi meningkat 1 maka akan meningkatkan keputusan memilih STIMI Meulaboh.

\section{Orang}

Berdasarkan Tabel 4 dapat diketahui bahwa t hitung $=10.452>\mathrm{t}$ tabel $=$ 1.985, dan signifikansi $=0.000<0.05$ maka $\mathrm{H}_{0}$ ditolak artinya orang atau tenaga 


\section{Jurnal Bisnis dan Kajian Strategi Manajemen}

Volume 3 Nomor 1, 2019

ISSN : 2614-2147

manusia berpengaruh positif dan signifikan terhadap keputusan mahasiswa memilih STIMI Meulaboh. Besarnya pengaruh promosi terhadap keputusanmemilih dilihat pada standardized coefficient (beta) sebesar 0.515

artinya jika persepsi atas sumber daya manusia kampus meningkat 1 maka akan meningkatkan keputusan memilih STIMI Meulaboh.

\section{Proses}

Berdasarkan Tabel 4 dapat diketahui bahwa $\mathrm{t}$ hitung $=2.731>\mathrm{t}$ tabel $=$ 1.985, dan signifikansi $=0.007<0.05$ maka $\mathrm{H}_{0}$ ditolak artinya proses berpengaruh positif dan signifikan terhadap keputusan mahasiswa memilih STIMI Meulaboh. Besarnya pengaruh proses terhadap keputusan memilih dilihat pada standardized coefficient (beta) sebesar 0.093. artinya jika persepsi atas proses meningkat 1 maka akan meningkatkan keputusan memilih STIMI Meulaboh.

\section{Bukti Fisik}

Berdasarkan Tabel 4 dapat diketahui bahwa $\mathrm{t}$ hitung $=2.475>\mathrm{t}$ tabel $=$ 1.985, dan signifikansi $=0.015<0.05$ maka $\mathrm{H}_{0}$ ditolak artinya bukti fisik dari kampus berpengaruh positif dan signifikan terhadap keputusan mahasiswa memilih STIMI Meulaboh. Besarnya pengaruh promosi terhadap keputusan memilih dilihat pada standardized coefficient (beta) sebesar 0.111 atau $11.1 \%$ artinya jika persepsi ata bukti fisik kampus meningkat 1 maka akan meningkatkan keputusan memilih STIMI Meulaboh.

Adapun persamaan yang memberikan model pengaruh bauran pemasaran jasa yang terdiri dari produk, harga, promosi, lokasi, orang, proses, serta bukti fisik dan terhadap keputusan memilih mahasiswa adalah sebagai berikut:

$$
\begin{gathered}
Y=0,106 X_{1}+0,137 X_{2}+0.214 X_{3}+0.515 X_{4}+0,093 X_{5}+0.111 X_{6} \\
+e
\end{gathered}
$$

\section{Pengaruh Produk Terhadap Keputusan Memilih}

Produk juga menjadi salah satu elemen penting yang harus menjadi fokus suatu perguruan tinggi, apabila produk tawaran perguruan tinggi baik maka akan mampu mempengaruhi pilihan mahasiswa artinya akan mampu memicu peningkatan jumlah keputusan memilih untuk melanjutkan kuliah pada perguruan tinggi tersebut. yang akhirnya kembali berdampak pada peningkatan keputusan 


\section{Jurnal Bisnis dan Kajian Strategi Manajemen}

Volume 3 Nomor 1, 2019

ISSN : 2614-2147

memilih melalui upaya merekomendasikan yang dilakukan oleh mahasiswa yang sedang atau telah melanjutkan di perguruan tinggi tersebut.

Hasil penelitian ini sesuai dengan hasil penelitian yang dilakukan Indrayani (2015) dimana produk berpengaruh terhadap keputusan memilih baik secara simultan maupun secara parsial juga sesuai dengan hasil penelitian Wati (2015), Sukendar (2015) dimana hasil penelitian menunjukkan bahwa produk secara parsial dan simultan berpengaruh positif dan signifikan terhadap keputusan memilih.

\section{Pengaruh HargaTerhadap Keputusan Memilih dan Kepuasan Mahasiswa}

Hal ini dapat saja terjadi karena meskipun STIMI Meulaboh menaikkan harga yang ditawarkan jika diikuti dengan peningkatan kualitas jasa yang ditawarkannya maka tidak akan berdampak pada penurunan keputusan pemilihan.

\section{Pengaruh Lokasi Terhadap Keputusan Memilih}

Paul (2000) berpendapat bahwa lokasi yang baik menjamin tersedianya akses yang cepat, dapat menarik sejumlah besar konsumen dan cukup kuat untuk mengubah pola berbelanja dan pembelian konsumen. Tjiptono (2014) mengatakan bahwa mood dan respon pelanggan dipengaruhi secara signifikan oleh lokasi, desain dan tata letak fasilitas jasa.

Dalam penelitian ini gedung STIMI Meulaboh letaknya sudah cukup strategis karena berada di kecamatan perbatasan dengan daerah pusat kota Aceh Barat dan lintasan kabupaten antar propinsi yaitu Propinsi Aceh dengan Propinsi Sumatera Utara.

\section{Pengaruh Orang Terhadap Keputusan Memilih.}

Menurut Hurriyati (2008) orang dalam jasa adalah orang-orang yang terlibat langsung dalam menjalankan segala aktivitas perusahaan, dan merupakan faktor yang memegang peranan penting bagi semua organisasi.

Berdasar hasil yang didapat di lapangan bahwa di STIMI Meulaboh masih mengalami kekurangan jumlah sumberdaya dosen tetap sehingga untuk memenuhi kebutuhan tersebut pihak STIMI Meulaboh banyak menggunakan dosen-dosen tetap dari perguruan tinggi lain.

Sedangkan untuk tenaga kependidikan yang ada dari hasil yang di dapatkan dilapang sebgaian besar tenaga kependidikan yang bekerja di STIMI 


\section{Jurnal Bisnis dan Kajian Strategi Manajemen}

Volume 3 Nomor 1, 2019

ISSN : 2614-2147

Meulaboh berlatar belakang tidak sesuai dengan tugas dan jabatan yang diembannya.

\section{Pengaruh Proses Terhadap Keputusan Memilih.}

Proses merupakan serangkaian aktivitas dalam upaya memenuhi kebutuhan serta kepuasan konsumen. Rangkaian aktivitas terdiri dari prosedur, wewenang, jadwal serta mekanisme yang bertalian dengan jasa yang diberikan kepada konsumen merupakan hal yang tidak boleh dilupakan oleh siapapun para penyedia jasa. Jelasnya proses tidak akan membuat bingung bagi konsumen, sebab jika hal tersebut terjadi konsumen enggan kembali untuk menikmati jasa yang ditawarkan di masa yang akan datang.

Hal ini sejalan dengan pendapat Zeithamal dan Bitner (2000) yang menyebutkan bahwa proses adalah the actual procedures, mechanism and flow of activities by which the service is delivered the service delivery and operating system. semua prosedur aktual, mekanisme, dan aliran aktivitas yang digunakan untuk menyampaikan jasa.

Proses dalam jasa merupakan faktor utama dalam bauran pemasaran jasa seperti pelanggan jasa akan sering merasakan sistem penyerahan jasa sebagai bagian dari jasa itu sendiri. Selain itu keputusan dalam manajemen operasi adalah sangat penting untuk suksesnya pemasaran jasa. Menurut Hurriyati (2005) Seluruh aktivitas kerja adalah proses, proses melibatkan prosedur-prosedur, tugastugas, jadwal-jadwal, mekanisme-mekanisme, aktivitas-aktivitas dan rutinitasrutinitas dengan apa produk atau jasa disalurkan ke pelanggan. Identifikasi manajemen proses sebagai aktifitas terpisah adalah prasyarat bagi perbaikan jasa. Pentingnya elemen proses ini khususnya dalam bisnis jasa disebabkan oleh persediaan jasa yang tidak dapat disimpan.

\section{Pengaruh Bukti Fisik Terhadap keputusan Memilih}

Hal ini juga sesuai dengan hasil penelitian terdahulu yang dilakukan oleh Indrayani (2011), Wati (2015) dan Taher (2013). dimana bukti fisik secara simultan dan parsial berpengaruh positif dan signifikan terhadap keputusan memilih

Menurut Tjiptono (2014), “ Karakteristik intangible pada jasa menyebabkan pelanggan potensial tidak bisa menilai suatu jasa sebelum mengkomsumsinya. 


\section{Jurnal Bisnis dan Kajian Strategi Manajemen}

Volume 3 Nomor 1, 2019

ISSN : 2614-2147

Oleh sebab itu, salah satu unsur penting dalam bauran pemasaran adalah upaya mengurangi tingkat resiko tersebur dengan jalan menawarkan bukti fisik dari karakteristik jasa. contoh nya penampilan staf yang rapi dan sopan.

\section{E. KESIMPULAN}

Berdasarkan hasil analisis dan pembahasan, adapun simpulannya sebagai berikut:

1. Secara parsial Produk,harga,lokasi,orang,proses dan bukti fisik berpengaruh positif dan signifikan terhadap keputusan memilih di STIMI Meulaboh.

2. produk, harga, lokasi, orang, proses, dan bukti fisik secara simultan berpengaruh signifikan terhadap keputusan memilih.

\section{DAFTAR PUSTAKA}

Adam,Muhamad. 2015. Manajemen Pemasaran Jasa. Bandung: Alfabeta 2011. Manajemen Pemasaran dan Pemasaran Jasa. Bandung : Penerbit Alfabeta.

Arikunto, Suharsimi. 2006. Prosedur Penelitian: Suatu Pendekatan Praktek, Edisi Revisi, Jakarta: Rineka Cipta.

Arikunto, Suharsimi , 2007. Manajemen Penelitian. Jakarta. Rineka Cipta

Hurriyati, Ratih. 2005. Bauran Pemasaran dan Loyalitas Konsumen. Edisi Pertama, Cetakan Pertama, Bandung: Alfabeta.

Kalsum EU, 2008.Analisis Pengaruh Strategi Bauran Pemasaran Terhadap Keputusan Mahasiswa Memilih Fakultas Ekonomi Universitas Al-Azhar Medan.Tesis. Program Studi Ilmu Manajemen Pascasarjana Universitas Sumatera Utara.

Kotler, Philip dan Kevin Lane Keller. 2009. Manajemen Pemasaran Edisi 13.Jilid 1. Jakarta : Erlangga.

Kotler,Philip dan Gary Armstrong. 2012.Prinsip-prinsip Pemasaran. Edisi 13. Jilid 1. Jakarta: Erlangga. 


\section{Jurnal Bisnis dan Kajian Strategi Manajemen}

Volume 3 Nomor 1, 2019

ISSN : 2614-2147

Lupiyoadi, Rambat, 2006.manajemen Pemasaran Jasa: Teori dan Praktek,Edisi Pertama.Jakarta: Salemba Empat.

Payne, Andrian, 2001. The Essence Of Service Marketing ,Diterjemahkan Oleh: Fandy Tjiptono, Edisi Pertama,Yogyakarta: Penerbit Andi

Sangadji EM dan Sopiah, 2013. Perilaku Konsumen Pendekatan dan Praktis Yogyakarta : Andi

Taher,Tasman. 2013. Pengaruh Bauran Pemasaran Terhadap Kepuasan layanan Jasa Pendidikan di Sekolah Tinggi Ilmu Ekonomi (STIE) Palangka Raya. Jurnal Sains Manajemen UNPAR. Vol II. No.2.

Tjiptono,Fandy,2007. Pemasaran Jasa. Malang : Banyumedia. 2014. Pemasaran Jasa. Yogyakarta: Andi

Umar Husein, 2005. Riset Pemasaran dan Perilaku Konsumen. Jakarta : PT Gramedia Pustaka Utama.

Yazid. 2008. Pemasaran Jasa: Konsep dan Implementasi. Yogyakarta.Ekonisia.

Zeithmal, Valarie A. And Mary Jo Bitner, Service Marketing: Integrating Customer Focus Across The Firm, Third Edition, North America 